International Journal of Constructive Research in Civil Engineering (IJCRCE)

Volume 3, Issue 3, 2017, PP 46-61

ISSN 2454-8693 (Online)

DOI: http://dx.doi.org/10.20431/2454-8693.0303005

www.arcjournals.org

\title{
Hydroelectric Production using Ab-Terki River Flow Specific Energy
}

Saeid Eslamian ${ }^{1}$, Nicolas R. Dalezios ${ }^{2}$, Mahboubeh Amoushahi-Khouzani ${ }^{3}$, Maryam MaraniBarzani $^{4}$, Amir Gandomkar ${ }^{5}$, Morteza Khodagholi ${ }^{6}$, Foroozan Rajaei-Rizi ${ }^{7}$, Vijay P. Singh ${ }^{8}$, Shahide Dehghan ${ }^{5}$, Mohsen Ghane', Kaveh Ostad-Ali-Askari ${ }^{10 *}$, Morteza Soltani ${ }^{11}$, Yohannes Yihdego $^{12}$, Hossein Norouzi ${ }^{13}$, Hamid-Reza Shirvani-Dastgerdi ${ }^{14}$

${ }^{I}$ Department of Water Engineering, Isfahan University of Technology, Isfahan, Iran.

${ }^{2}$ Laboratory of Hydrology, Department of Civil Engineering, University of Thessaly, Volos, Greece \& Department of Natural Resources Development and Agricultural Engineering, Agricultural University of Athens, Athens, Greece.

${ }^{3}$ Water Engineering Department, Science and Research Branch, Islamic Azad University, Tehran, Iran

${ }^{4}$ Department of Geography, University of Malaya (UM) ,50603 Kuala Lumpur, Malaysia.

${ }^{5}$ Department of Geography, Najafabad Branch, Islamic Azad University, Najafabad, Iran

${ }^{6}$ Isfahan Center for Research of Agricultural Science and Natural Resources, Department of Climate Change \& Drought, Isfahan, Iran.

${ }^{7}$ Water Engineering Department, Shahrekord University, Shahrekord, Iran

${ }^{8}$ Department of Biological and Agricultural Engineering \& Zachry Department of Civil Engineering, Texas A and M University, 321 Scoates Hall, 2117 TAMU, College Station, Texas 77843-2117, U.S.A.

${ }^{9}$ Department of Civil Engineering, South Tehran Branch, Islamic Azad University, Tehran, Iran

${ }^{10 *}$ Department of Civil Engineering, Isfahan (Khorasgan) Branch, Islamic Azad University, Isfahan, Iran

${ }^{11}$ Department of Architectural Engineering, Shahinshahr Branch, Islamic Azad University, Shahinshahr, Iran

${ }^{12}$ Snowy Mountains Engineering Corporation (SMEC), Sydney, New South Wales 2060, Australia.

GeoInformation Science and Earth Observation (ITC), University of Twente, the Netherlands

${ }^{13}$ Department of Civil Engineering, Maybod Branch, Islamic Azad University, Maybod, Yazd, Iran

${ }^{14}$ Department of Civil Engineering, Isfahan (Khorasgan) Branch, Islamic Azad University, Isfahan, Iran

*Corresponding Author: Dr. Kaveh Ostad-Ali-Askari, Department of Civil Engineering, Isfahan (Khorasgan) Branch, Islamic Azad University, Isfahan, Iran.Email: Koa.askari@khuisf.ac.ir

Abstract: The flow duration curve (FDC) of a riveris one of the important parameters for the hydrological investigation of hydroelectric plants. Computation of the hydroelectric plant capacity and power production requires the determination of relative and cumulative frequenciesof different river discharges. Ab-Terki is one of the sub-basins of Bazoft River, located in Chaharmahal and Bakhtiari province, Iran, next to Koohrang basin. It is located between eastern longitudes of 49 54' to 50 5' and northern latitudes of $32^{\circ} 19^{\prime}$ to $32^{\circ} 24^{\prime}$. Morphological conditions, sloping limestone structures, and characteristics of karstic cracks in the basin have led to the formation of large springs in the eastern and western foothills of Zardkooh Mountain. In order to determine the FDCs of Ab-Terki River,3-year daily discharge and 24-year mean monthly discharge of Gooshe-pol station were used. Then, the probabilities of discharges were analyzed using Hyfa and Rank Plot numerical codes and finally, the discharge of Ab-Terki River corresponding to $95 \%$ probability was determined.

Keywords: Hydroelectric, Ab-Terki, Bazoft, duration curve, mean daily discharge, mean monthly discharge, flow frequency analysis 


\section{INTRODUCTION}

Ab-Terki River basin covers Ab-Terki River and its tributaries and is limited to Koohrang basin from the East, Bazoft basin from the West and South and Tashnavi basin from the North. The basin with an area of about 90.4 square kilometers is located between eastern longitudes of $49^{\circ} 54^{\prime}$ to $50^{\circ} 5^{\prime}$ and northern latitudes of $32^{\circ} 19^{\prime}$ to $32^{\circ} 24^{\prime}$. Ab-Terki River has a relatively wide basin, limited by Zardkooh and Koohgerd mountains. The geomorphology and geology governing the flow regime of Koohrang, Ab-Terki and Bazoft riversis such that micro and macro porous limestone serves as a reservoir interfacing between snow and rain input and springs output. The flows form the base discharge or the underground element of the total river flow. The impact of this element in the basin under study is significant in comparison to the net surface flow due to flood generating rainfall. Considering the river flow potential for power production, this study determined the flow duration curves(FDCs) of Ab-Terki River in order to estimate the hydroelectric power that the river can produce[1-2].

\section{Materials ANd Methods}

Bazoft is a mountainous basin located in Zagros Mountains and is limited to Zardkooh, Chehel khesht, Cherie, Meyli, Haft CHeshmeh, Gandomkar from the Northeast; Sheshbar mountain from the Southeast; Ateh, Lapeh, Sefid, Foolad, Darre Deli, Manazon, Foogeh, Tarazof Lalar, Maqar in the Southwest; and the rest of Zardkooh in the Northwest. The area of the basin to the Morghak hydrometric station, i.e., about three kilometers to its intersection with Karun River, is 2169 square kilometers with a quite long shape located between the eastern longitudes of $34^{\circ} 49^{\prime}$ and $31^{\circ} 50^{\prime}$ and northern latitudes of $31^{\circ} 37^{\prime}$ and $32^{\circ} 39^{\prime}$. Due to its long shape, the river, which is the only main drain of the basin, starts from the highest point in the northwest at an altitude of $3700 \mathrm{~m}$ and elongates to the southeast in a relatively straight line on a distance of $160 \mathrm{~km}$. It joins the Karun River at an altitude of 860 meters at the southeastern end of the basin. The headwater stream consists of a number of important and full of water branches, along which several additional branches are added. The headwater stream of these branches and around the river mostly consists of permanent water springs. The Morghak hydrometric station, located near the junction of Bazoft and Karun Rivers, was established in 1335. Statistics of 21-year discharge record from 1340 to 1361 were analyzed. Evaluation of rainfall in the mountains requires a dense network of barometric and snow measuring devices that can monitor the amount and spatial variation of snow and rainfall on different slopes and altitudes. Unfortunately, such areas not only do not have such a network but even the existing systems do not perform efficiently. However, rainfall statistics of six stations were available in the study area and around it. These stations and their statistical period were:

- Gooshe pol rain gaugestation located in the Ab-Terki Riverbas in with a 9-year statistical period

- Morghakrain gauge station located in the Bazoft River basin with a 27-year statistical period

- Chelgerd rain gauge station located in the Koohrang basin with a 29-year statistical period

- Shahrekord synoptic station with a 14-year statistical period

- Koohrang synoptic station with a 7-year statistical period

- Borujen synoptic stations with a 6-year statistical period

Given the lack of accurate statistics in the basin, statistics of other weather stations were used. It should be noted that except 3-year daily discharge and 9-year monthly rainfall statistics of Gooshepol station located on the Ab-Terki River, no other information was available and thus, analysis of the necessary parameters was done using the statistics of other three rain gauge and three hydrometric stations in the area. These stations provided acceptable statistics of annual and monthly rainfall amounts and therefore, rainfall and its temporal variations were evaluated considering this data [3-9].

The water budget of the Ab-Terki basindid not balance in most months and years with available statistics. Therefore, the output runoff obtained from direct measurements at the hydrometric stations was more than input value (acceptable precipitation in the basin). Thus, the hydrologic budget relation could not be used for determining discharge for the years that had no statistics.

Using the annual rainfall statistics of the Morghak and Chelgerd stations, which had the longest statistical period as well as Gooshepol station located within the study basin, annual changes of rainfall were evaluated and analyzed for the three mentioned stations. 
Given the lack of temperature values at the Gooshepol station, the statistics of Koohrang synoptic station, the nearest weather station to the study area, were used.

Climate is the most important environmental parameter that plays a vital role in the life of organisms. Different parameters such as latitude, altitude, topography, distance and proximity to the sea and the location with regard to the regional and continental flows will form different climates in a region. Various methods have been proposed for the determination of climate among which are Demarton, Emberger, and Coupon methods in which temperature and rainfall play a major role.

\subsection{The Demartini Method}

In this method, the climate is classified as follows:

$$
I=\frac{P}{T+10}
$$

$\mathrm{P}$ : the average annual precipitation $(\mathrm{mm})$

T: the average annual temperature $\left({ }^{\circ} \mathrm{C}\right)$

I: the drought coefficient

The climate classification is shown in Table 2.

Table1. Physiographic characteristics of the Ab-Terki River basin

\begin{tabular}{|c|c|c|c|}
\hline Parameter & Index & Value & Unit \\
\hline Area & $\mathrm{A}$ & 90.4 & $\mathrm{Km}^{2}$ \\
\hline Perimeter & $\mathrm{P}$ & 54.75 & $\mathrm{Km}$ \\
\hline Basin length along the main channel & 1 & 16.75 & $\mathrm{Km}$ \\
\hline The longest basin axis & $\mathrm{L}^{\prime}$ & 17.7 & $\mathrm{Km}$ \\
\hline The main channel length & $\mathrm{L}$ & 91 & $\mathrm{Km}$ \\
\hline The total length of the stream & $\Sigma_{\mathrm{L}}$ & 23.69 & $\mathrm{Km}$ \\
\hline Equivalent rectangle length & $\mathrm{LO}$ & 3.816 & $\mathrm{Km}$ \\
\hline Equivalent rectangle width & $\mathrm{BO}$ & 10.73 & $\mathrm{Km}$ \\
\hline Equivalent circle diameter & $\mathrm{D}$ & 1.62 & $\mathrm{Km}$ \\
\hline Gravilious coefficient & $\mathrm{C}$ & 1.62 & - \\
\hline Skewness (Kurtosis) coefficient & $\mathrm{Re}$ & 0.606 & - \\
\hline Circular ratio & $\mathrm{Rc}$ & .38 & - \\
\hline Shape coefficient & $\mathrm{Ff}$ & .161 & - \\
\hline Density of the river network & $\mu$ & 1.02 & $\mathrm{Km} / \mathrm{Km}{ }^{2}$ \\
\hline Average slope of the main channel & $\mathrm{S}$ & 7.44 & $\%$ \\
\hline Maximum height gradient of the main channel & $\mathrm{H}$ & 2380 & $\mathrm{~meter}$ \\
\hline Output point elevation & $\mathrm{Hmin}$ & 1570 & $\mathrm{~meter}$ \\
\hline Center of gravity distance to the basin outlet & $\mathrm{Hmax}$ & 3950 & $\mathrm{~meter}$ \\
\hline
\end{tabular}

Table2.Climate classification based on Demarton method

\begin{tabular}{|c|c|}
\hline Climate & Demarton coefficient range \\
\hline Arid & Less than 10 \\
\hline Semi-arid & $10-19.9$ \\
\hline Mediterranean & $20-23.9$ \\
\hline Semi-wet & $24-27.9$ \\
\hline Wet & $28-34.9$ \\
\hline Very wet & Great than 35 \\
\hline
\end{tabular}

\subsection{The Emberger Method}

In this method, the climate is classified as:

$$
Q_{2}=\frac{2000 p}{M^{2}-m^{2}}
$$


P: the average annual precipitation $(\mathrm{mm})$

M: the average of maximum temperatures in the hottest month of the year ( $\left.{ }^{\circ} \mathrm{Kelvin}\right)$

$\mathrm{m}$ : the average of minimum temperatures in the coldest month of the year ( $\left.{ }^{\circ} \mathrm{Kelvin}\right)$

$\mathrm{Q}_{2}$ : The Emberger coefficient

By obtaining the Emberger coefficient and using Fig. 1, the climate of the region can be determined.

The climate of the Ab-Terki River basin is affected by the climate of the adjacent Koohrang basin. According to observations, high parts of the Ab-Terki basin have a cold and wet mountain climate and low parts and Bazoft River bank areas have a moderate and wet climate. In this study, the climate of the area was determined using two methods [10-19].

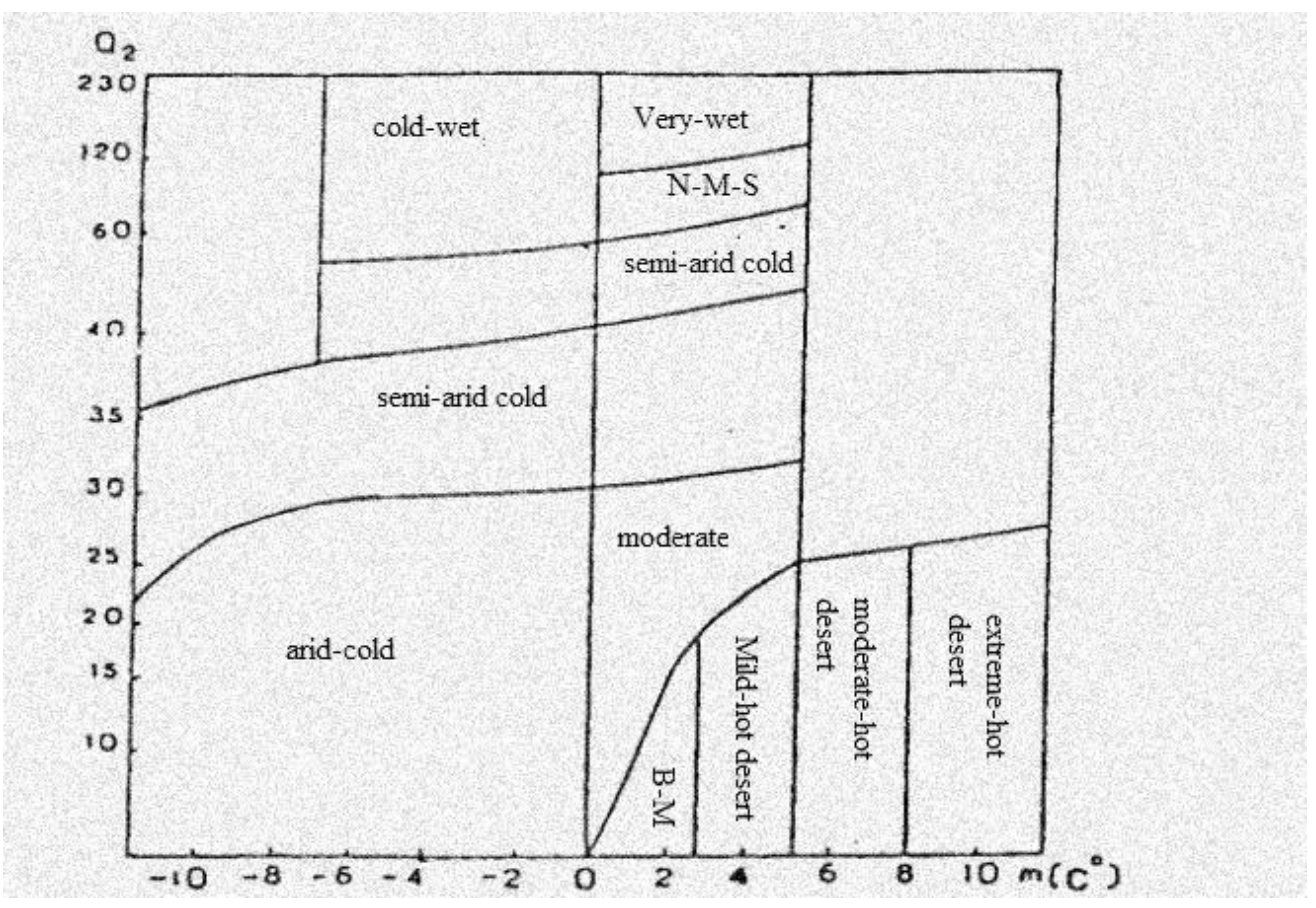

Figure1. Climate classification using the Emberger method

Due to the high altitude of the Ab-Terki basin, many frosty days occur in the basin and considering the lack of statistics in the area, available statistics of the nearest Koohrang station were analyzed.

Wind is one of the climatic parameters and was available at Koohrang, Borujen (5-year data), and Shahrekord (9-year data) stations. At these three stations, the average monthly and annual wind speeds were calculated for their statistical periods using weighting average of the wind speed in 8 directions of the north, northeast, east, southeast, south, southwest, west, and northwest. The wind speed at $10 \mathrm{~m}$ height was calculated using the following formula:

$$
\frac{U}{U_{0}}=\left(\frac{Z}{Z_{0}}\right)^{0.15}
$$

$\mathrm{U}_{0}$ : the wind speed at the height of $\mathrm{Z}_{0}$ from the ground surface

$\mathrm{U}$ : the wind speed at the height of $\mathrm{Z}$ from the ground surface

In the presence of detailed discharge data at the outlet or a certain point in the basin, the volume of flow at monthly or annual scale can beestimatedusinghydrologicbudget methods. There is no doubt that the estimated value is close to the real value in such a condition that an accurate evaluation of all the involved parameters can be done at the desired timescale. This condition is fulfilled when, first, the basin topography and geology are known, or any flow exchange with adjacent basins, whether in the form of surface flow or underground flow, can be controlled and determined. Second, complete data of input and output climate parameters, either in the form of rainfall or evapotranspiration, would be available in the form of long-term reliable statistics. Third, basin response to the interaction, either in the form of water penetration and deep percolation or feeding surface flows from underground resources or in short, its storage characteristics in the selected parts would be known for determining the water budget [20-39]. 
The concentration time of a basin is the time that a drop of water travels from the farthest point (on a temporal basis) of the basin to the basin outlet. the concentration time of the Ab-Terki basin was estimated using different formulae [40-54].

\section{- Pacini[check] method}

$$
t_{c}=0.108 \frac{(A L)^{\frac{1}{3}}}{\sqrt{S}}
$$

L: the length of the main channel $(\mathrm{km})$

A: the basin area (square kilometers)

$\mathrm{S}$ : the average slope of the main channel $(\mathrm{m} / \mathrm{m})$

\section{- Chow method}

$$
t_{c}=0.00032 \frac{L^{1.15}}{H^{0.385}}
$$

$\mathrm{L}$ : the length of the main channel (m)

$\mathrm{H}$ : the maximum height difference of the main channel (m)

\section{- Branzli-Williams method}

$$
t_{c}=\frac{L}{1.5 D} \sqrt[3]{\frac{A^{2}}{S}}
$$

$\mathrm{L}$ : the length of main channel $(\mathrm{km})$

D: the diameter of the equivalent circle $(\mathrm{km})$

A: the basin area (in square kilometers)

$\mathrm{S}$ : the average slope of the main channel (\%)

\section{- Kirpich method-type I}

$t_{c}=0.0003 L^{0.77} S^{-0.385}$

L: the length of main channel (m)

$\mathrm{S}$ : the average slope of the main channel $(\mathrm{m} / \mathrm{m})$

\section{- Kirpich method-type II}

$$
t_{c}=0.949\left(\frac{L^{3}}{H}\right)^{0.385}
$$

$\mathrm{L}$ : the length of the main channel $(\mathrm{km})$

$\mathrm{H}$ : the maximum elevation difference of the main channel (m)

Flood evaluation of a basin without discharge data was performed using the following methods:

1. Using the available maximum annual instantaneous discharge data for the maximum average daily discharge

2. Regional analysis for the determination of flood specific peak discharge

3. The area-discharge method

The third method was used based on the following formula: 


$$
Q_{T \sigma}=Q_{B a z} \times \frac{A_{T \digamma}}{A_{B a z}}
$$

where $\mathrm{Q}_{\mathrm{Ter}}$ and $\mathrm{Q}_{\mathrm{Baz}}$ indicate the Ab-Terki and Bazoft River peak discharges, respectively, and $\mathrm{A}_{\mathrm{Ter}}$ and $\mathrm{A}_{\mathrm{Baz}}$ indicate the areas of the Ab-Terki and Bazoft basins.

\section{RESULTS AND DISCUSSION}

In order to determine the study area climate, Demarton and Emberger methods were used. Using Do marten method, I=69.19 was obtained and thus, Ab-Terki basin was classified as a very wet area. Using Emberger method and considering Fig. 1, the basin climate was classified as a cold and mountainous one.

The prevailing wind at Shahrekord, Borujen and Koohrang stations was equal to $20 \mathrm{~m} / \mathrm{son}$ the $1^{\text {st }}$ of February, $1985,18 \mathrm{~m} / \mathrm{s}$ on the $20^{\text {th }}$ of May, 1992and $30 \mathrm{~m} / \mathrm{s}$ on the $9^{\text {th }}$ of December, 1991, respectively.

The concentration time of the study basin was calculated using Pacini, Chow, Kirpich Type-I, Kirpich Type-II and Branzli-Williams formulas and results are shown in Table 3.

Table3. Concentration time of the study basin using different methods

\begin{tabular}{|c|c|}
\hline Method & Concentration time (hour) \\
\hline Pacini & 0.45 \\
\hline Chow & 1.23 \\
\hline Kirpich Type-I & 4.44 \\
\hline Kirpich Type-II & 1.51 \\
\hline Branzli-Williams & 1.31 \\
\hline
\end{tabular}

Because of significant differences between the results obtained from the Pacini and Branzli-Williams formulas and other methods, two methods were discarded and the average concentration time, using the other three methods, was found as $1.51 \mathrm{~h}$.

Table4. Annual and maximum daily and instantaneous discharges of the Bazoft River at Morghak station in the desired statistical period 1961-1982

\begin{tabular}{|c|c|c|c|c|c|}
\hline \multirow{2}{*}{ Water year } & Annual discharge & \multicolumn{2}{|c|}{ Daily discharge } & \multicolumn{2}{c|}{ Instant discharge } \\
\cline { 3 - 6 } & & $\begin{array}{c}\text { Occurrence } \\
\text { date }\end{array}$ & Maximum & Maximum & Probability \\
\hline $1962-1963$ & 55.3 & $22 / 04 / 1962$ & 311 & 815 & 54.5 \\
\hline $1963-1964$ & 48.3 & $11 / 04 / 1963$ & 246 & 591 & 81.8 \\
\hline $1964-1965$ & 43.1 & $13 / 03 / 1964$ & 532 & 870 & 45.5 \\
\hline $1965-1966$ & 55.6 & $1965 / 02 / 14$ & 459 & 797 & 59.1 \\
\hline $1966-1967$ & 57.3 & $1966 / 03 / 14$ & 735 & 917 & 40.9 \\
\hline $1967-1968$ & 42.5 & --- & --- & 402 & 95.9 \\
\hline $1968-1969$ & 54.5 & $1968 / 04 / 24$ & 432 & 1115 & 27.3 \\
\hline $1969-1970$ & 109 & --- & --- & 2240 & 4.55 \\
\hline $1970-1971$ & 45.2 & $1970 / 03 / 20$ & 421 & 459 & 90.9 \\
\hline $1971-1972$ & 46.2 & $1971 / 04 / 13$ & 432 & 760 & 68.2 \\
\hline $1972-1973$ & 85.1 & $1972 / 03 / 23$ & 700 & 1136 & 22.7 \\
\hline $1973-1974$ & 57.1 & $1973 / 02 / 22$ & 444 & 608 & 77.3 \\
\hline $1974-1975$ & 62.2 & --- & --- & 1040 & 36.4 \\
\hline $1975-1976$ & 60.6 & $1975 / 01 / 04$ & 287 & 467 & 86.4 \\
\hline $1976-1977$ & 119 & $1976 / 02 / 11$ & 964 & 1836 & 13.6 \\
\hline $1977-1978$ & 47.6 & $1977 / 03 / 04$ & 353 & 635 & 72.7 \\
\hline $1979-1980$ & 81.4 & $1977 / 12 / 13$ & 844 & 1362 & 18.2 \\
\hline $1980-1981$ & 53.5 & $1978 / 12 / 06$ & 719 & 1053 & 31.8 \\
\hline $1981-1982$ & 109 & $1980 / 04 / 15$ & 1116 & 2081 & 9.1 \\
\hline $1982-1983$ & 66 & $1981 / 02 / 21$ & 473 & 867 & 50 \\
\hline $1983-1984$ & 76.2 & $1982 / 03 / 26$ & 585 & 772 & 63.6 \\
\hline
\end{tabular}

Table 4shows the annual discharge (annual average of monthly discharge), the maximum of mean daily discharge and the maximum annual instantaneous discharge of the Bazoft River at the Morghak station for the period of 1340 to 1361 . The Weibull formula was used to calculate the probabilities of 
extreme events. The largest flood of $2240 \mathrm{~m}^{3} / \mathrm{s}$ occurred in the water year of 1347-1348. Table 5 shows the average monthly discharge. As can be seen, April and October were the wet months and least watery months of the year for the Bazoft River at the Morghak station. The average annual discharge and annual flood volume of the Bazoft River at Morghak station were estimated for different return periods, based on the log-normal distribution. For a 100-year return period (1\% probability of occurrence), average annual discharges of the drought and wet periods were estimated as $34.5 \mathrm{~m}^{3} / \mathrm{s}$ and $245 \mathrm{~m}^{3} / \mathrm{s}$, respectively. The volumes of extracted water in this return period were determined as $1088 \mathrm{MCM}$ and $7726 \mathrm{MCM}$, respectively.

Table5. Occurrence probability of the average monthly discharge of the Bazoft River at the Morghak station1961-1982

\begin{tabular}{|c|c|c|c|c|c|c|c|c|c|c|c|c|}
\hline Aug & July & June & May & Apr & Mar & Feb & Jan & Dec & Nov & Oct & sep & Probability \\
\hline 60 & 72 & 110 & 191 & 283 & 432 & 221 & 221 & 120 & 114 & 86.5 & 37 & $\begin{array}{c}\text { Maximum } \\
\text { discharge }\end{array}$ \\
\hline 38.8 & 61.4 & 94.4 & 137 & 224 & 284 & 172 & 135 & 82.8 & 84.1 & 34.6 & 25.7 & $10 \%$ \\
\hline 27.8 & 32.9 & 56.4 & 90.9 & 170 & 214 & 140 & 93.9 & 42.4 & 43.9 & 27.5 & 23.3 & $25 \%$ \\
\hline 22.5 & 28.4 & 40.2 & 64.4 & 109 & 137 & 110 & 56.1 & 31.7 & 32.6 & 22.5 & 21 & $50 \%$ \\
\hline 20 & 24.5 & 33.9 & 52.3 & 82.6 & 107 & 93.6 & 38.1 & 26.2 & 22.1 & 19.2 & 19.1 & $75 \%$ \\
\hline 19.2 & 22.8 & 29.1 & 47.7 & 74.4 & 82.5 & 76.1 & 23.4 & 19.5 & 18.8 & 17 & 15 & $100 \%$ \\
\hline 16 & 19.8 & 28.4 & 45.9 & 69 & 75.8 & 68.3 & 21.4 & 18.9 & 17.3 & 14.1 & 14.8 & $\begin{array}{c}\text { minimum } \\
\text { discharge }\end{array}$ \\
\hline
\end{tabular}

Due to the lack of statistical years, the results of Bazoft River data were fitted with the Log-Pearson type III distribution. From this distribution, the peak discharge of the BazoftRiver at the Morghak station for a 1000-year return period was estimated as $5418 \mathrm{~m}^{3} / \mathrm{s}$. Then, using three years of daily statistics and 24 years of average monthly discharge measured at Gooshepol station (prolonged statistics),results were obtained as shown in Tables 6 and 7, and an average of the two methods is shown in Fig. 2. The river continuity curve was drawn so that the number of days with the minimum necessary flow in order to produce electricity could be estimated.

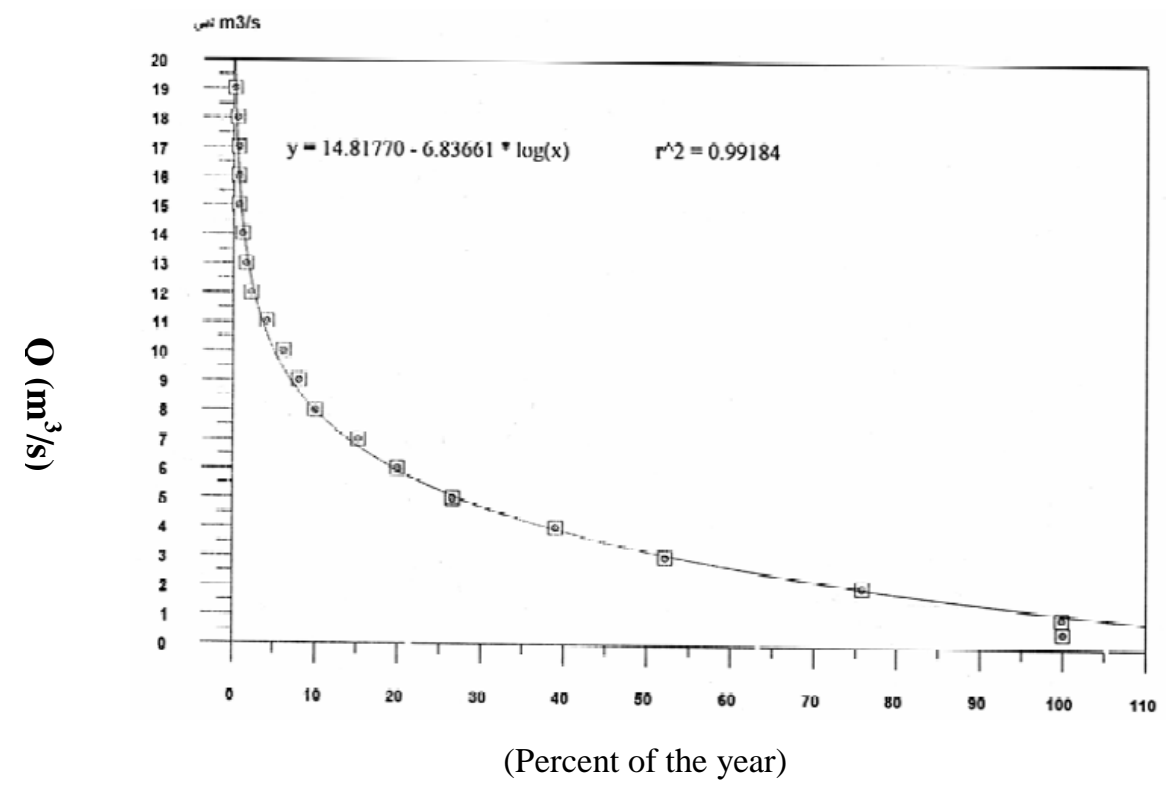

Figure2. Flow duration curve of Ab-Terki River

Table6. Discharge, relative and cumulative frequencies of the Gooshepol station based on three years of daily statistics

\begin{tabular}{|c|c|c|c|c|}
\hline $\begin{array}{c}\text { Cumulative } \\
\text { frequency (\%) }\end{array}$ & $\begin{array}{c}\text { Cumulative } \\
\text { frequency (day) }\end{array}$ & Discharge limit & $\begin{array}{c}\text { Relative frequency } \\
\text { (day) }\end{array}$ & $\begin{array}{c}\text { Discharge } \\
\text { classification } \\
\left(\mathrm{m}^{3} / \mathrm{s}\right)\end{array}$ \\
\hline 0.36 & 4 & $>19.01$ & 4 & $\geq 19.01$ \\
\hline 0.63 & 7 & $>18.01$ & 3 & $18.01-19$ \\
\hline 0.63 & 7 & $>17.01$ & 0 & $17.01-18$ \\
\hline 0.63 & 7 & $>16.01$ & 0 & $16.01-17$ \\
\hline
\end{tabular}


Hydroelectric Production using Ab-Terki River Flow Specific Energy

\begin{tabular}{|c|c|c|c|c|}
\hline 0.73 & 8 & $>15.01$ & 1 & $15.01-16$ \\
\hline 0.91 & 10 & $>14.01$ & 2 & $14.01-15$ \\
\hline 1.09 & 12 & $>13.01$ & 2 & $13.01-14$ \\
\hline 2 & 22 & $>12.01$ & 24 & $12.01-13$ \\
\hline 4.19 & 46 & $>11.01$ & 14 & $10.01-11$ \\
\hline 5.47 & 60 & $>10.01$ & 14 & $9.01-10$ \\
\hline 6.74 & 74 & $>9.01$ & 35 & $8.01-9$ \\
\hline 9.94 & 109 & $>8.01$ & 48 & $7.01-8$ \\
\hline 14.32 & 157 & $>7.01$ & 41 & $6.01-7$ \\
\hline 18.06 & 198 & $>6.01$ & 77 & $5.01-6$ \\
\hline 25.09 & 275 & $>5.01$ & 135 & $4.01-5$ \\
\hline 37.40 & 410 & $>4.01$ & 173 & $3.01-4$ \\
\hline 53.19 & 583 & $>3.01$ & 154 & $2.01-3$ \\
\hline 67.24 & 737 & $>2.01$ & 356 & $1.01-2$ \\
\hline 99.73 & 1093 & $>1.01$ & 3 & $0.5-1$ \\
\hline 100 & 1096 & $>0.5$ & & \\
\hline
\end{tabular}

Table7. Discharge and relative and cumulative frequencies of the Gooshepol station based on 24yearsof average monthly discharges (prolonged statistics)

\begin{tabular}{|c|c|c|c|c|}
\hline $\begin{array}{c}\text { Cumulativefrequency } \\
(\%)\end{array}$ & $\begin{array}{c}\text { Cumulativefrequency } \\
(\text { day })\end{array}$ & Discharge limit & $\begin{array}{c}\text { Relative } \\
\text { frequency (day) }\end{array}$ & $\begin{array}{c}\text { Discharge } \\
\text { classification } \\
\left(\mathrm{m}^{3} / \mathrm{s}\right)\end{array}$ \\
\hline 0 & 0 & $>19.01$ & 0 & $\geq 19.01$ \\
\hline 0.34 & 1 & $>18.01$ & 1 & $18.01-19$ \\
\hline 0.69 & 2 & $>17.01$ & 0 & $16.01-18$ \\
\hline 0.69 & 2 & $>16.01$ & 0 & $15.01-16$ \\
\hline 0.69 & 2 & $>15.01$ & 2 & $14.01-15$ \\
\hline 1.38 & 4 & $>14.01$ & 2 & $13.01-14$ \\
\hline 2.08 & 6 & $>13.01$ & 1 & $12.01-13$ \\
\hline 2.42 & 7 & $>11.01$ & 5 & $11.01-12$ \\
\hline 4.16 & 12 & $>10.01$ & 8 & $9.01-10$ \\
\hline 6.94 & 20 & $>9.01$ & 7 & $8.01-9$ \\
\hline 9.37 & 27 & $>8.01$ & 2 & $7.01-8$ \\
\hline 10.06 & 29 & $>7.01$ & 17 & $6.01-7$ \\
\hline 15.97 & 46 & $>6.01$ & 17 & $5.01-6$ \\
\hline 21.87 & 63 & $>5.01$ & 18 & $4.01-5$ \\
\hline 28.12 & 81 & $>4.01$ & 36 & $3.01-4$ \\
\hline 40.62 & 117 & $>3.01$ & 39 & $2.01-3$ \\
\hline 54.16 & 156 & $>2.01$ & 87 & $1.01-2$ \\
\hline 84.37 & 243 & $>0.5$ & 45 & $0.5-1$ \\
\hline 100 & 288 & 288 & 0 & 0.11 \\
\hline 100 & & & & 0 \\
\hline
\end{tabular}

According to flow duration curve obtained for the river, river discharge exceeded $1.9 \mathrm{~m}^{3} / \mathrm{s}, 2.2 \mathrm{~m}^{3} / \mathrm{s}, 3$ $\mathrm{m}^{3} / \mathrm{s}$, and $3.5 \mathrm{~m}^{3} / \mathrm{sat} 90 \%, 80 \%, 70 \%$ and $50 \%$ of the year, respectively. Thus, by changing the discharge occurrence probability from $90 \%$ to $80 \%, 80 \%$ to $70 \%$, and $70 \%$ to $50 \%$ the minimum discharge increased by $15.7 \%, 36.4 \%$ and $16.6 \%$, respectively.

For the purpose of flood control and water delivery to a hydroelectric plant, flood maximum discharge should be estimated. For flood estimation in the area, the following two methods were used:

1. Using the available data of maximum annual instantaneous discharge. Because of the lack of daily discharge data during three water years of 69-70, 73-74, and 75-76 and the lack of the maximum annual instantaneous discharge data, this method was not used.

2. Regional evaluation for determining the specific maximum flood discharge. After evaluation and using flood data of the Bazoft River, the statistical period of 1335-71 was analyzed. Results of floods with different return periods in the Bazoft and Ab-Terki Rivers are shown in Table 8. The logarithmic Gumbel distribution was the most appropriate distribution fitting the flood data (Table 9). Therefore, the average annual discharge and flood volume of the Bazoft River at Morghak station were estimated for different return periods using the log-normal distribution. It should be 
Hydroelectric Production using Ab-Terki River Flow Specific Energy

noted that the flood maximum discharge of the Ab-Terki River was obtained using the flood maximum discharge of the Bazoft River.

Table8. Results of flood analysis for the Bazoft and Ab-Terki Rivers at the Morghak and Gooshepol stations, respectively (using logarithmic Gumbel distribution)

\begin{tabular}{|c|c|c|}
\hline $\begin{array}{l}\text { Maximum flood discharge of the } \\
\text { Ab-Terki River }\left(\mathrm{m}^{3} / \mathrm{s}\right)\end{array}$ & $\begin{array}{c}\text { Maximum flood discharge of the } \\
\text { Bazoft River }\left(\mathrm{m}^{3} / \mathrm{s}\right)\end{array}$ & Return period (T) \\
\hline 32.82 & 787.56 & 2 \\
\hline 46.28 & 1110.62 & 5 \\
\hline 58.12 & 1394.44 & 10 \\
\hline 77.48 & 1858.99 & 25 \\
\hline 95.9 & 2301.02 & 50 \\
\hline 118.52 & 2843.67 & 100 \\
\hline 146.35 & 3511.57 & 200 \\
\hline 193.32 & 4638.5 & 500 \\
\hline 214.64 & 5150 & 750 \\
\hline 238.58 & 5724.51 & 1000 \\
\hline 295.91 & 7100 & 10000 \\
\hline
\end{tabular}

Table9. Results of flood analysis in the Bazoft River at the Morghak station $\left(\mathrm{m}^{3} / \mathrm{s}\right)$

\begin{tabular}{|c|c|c|c|c|c|c|c|c|c|c|c|}
\hline \multirow[t]{2}{*}{1000} & \multirow[t]{2}{*}{500} & \multirow[t]{2}{*}{200} & \multirow[t]{2}{*}{100} & \multirow[t]{2}{*}{50} & \multirow[t]{2}{*}{25} & \multirow[t]{2}{*}{20} & \multirow[t]{2}{*}{10} & \multirow[t]{2}{*}{5} & \multirow[t]{2}{*}{2} & $\begin{array}{l}\text { Return Period } \\
\text { (Year) }\end{array}$ & \multirow[t]{2}{*}{ Number } \\
\hline & & & & & & & & & & $\begin{array}{c}\text { Statistical } \\
\text { distribution }\end{array}$ & \\
\hline 3931 & 3551 & 3065 & 2718 & 2382 & 2059 & 1955 & 1640 & 1326 & 883 & $\begin{array}{c}\text { Two- } \\
\text { parameter } \\
\text { Log-normal } \\
\text { distribution } \\
\text { (probability } \\
\text { factor) }\end{array}$ & 1 \\
\hline 37983 & 3441 & 2983 & 2653 & 2334 & 2024 & 1926 & 1624 & 1320 & 889 & $\begin{array}{c}\text { Two- } \\
\text { parameter } \\
\text { Log-normal } \\
\text { distribution } \\
\text { (normal } \\
\text { variable) }\end{array}$ & 2 \\
\hline 3505 & 3230 & 2865 & 2589 & 2312 & 2033 & 1942 & 1656 & 1358 & 908 & Gumble & 3 \\
\hline 9052 & 7019 & 5014 & 3885 & 3008 & 2324 & 2137 & 1642 & 1247 & 823 & $\begin{array}{c}\text { Logarithmic } \\
\text { Gumble }\end{array}$ & 4 \\
\hline 3580 & 3301 & 2925 & 2641 & 2354 & 2064 & 1968 & 1667 & 1352 & 885 & $\begin{array}{c}\text { Pearson type } \\
\text { III }\end{array}$ & 5 \\
\hline 4837 & 4222 & 3485 & 2991 & 2542 & 2134 & 2010 & 1645 & 1305 & 864 & $\begin{array}{c}\text { Logarithmic } \\
\text { Pearson type } \\
\text { III }\end{array}$ & 6 \\
\hline 5418 & 4659 & 3770 & 3189 & 2672 & 2212 & 2073 & 1675 & 1312 & 857 & $\begin{array}{c}\text { Adjusted } \\
\text { Logarithmic } \\
\text { Pearson type } \\
\text { III } \\
\end{array}$ & 7 \\
\hline 3373 & 3134 & 2818 & 2579 & 2340 & 2101 & 2024 & 1786 & 1547 & 1231 & Fooler & 8 \\
\hline
\end{tabular}

3. Area-discharge method. Myer experimental method was used and results are shown in Table 10.

Table10. Estimation of probable maximum flood discharge in Ab-Terki River basin using Myer method

\begin{tabular}{|c|c|c|}
\hline Coefficient & $\begin{array}{c}\text { Maximum flood discharge of the } \\
\text { Ab-Terki River }\left(\mathrm{m}^{3} / \mathrm{s}\right)\end{array}$ & Return period (year) \\
\hline 4.4 & 65.63 & 2 \\
\hline 6.0 & 89.5 & 5 \\
\hline 7.1 & 105.91 & 10 \\
\hline 9.4 & 140.22 & 100 \\
\hline 10.4 & 155.14 & 1000 \\
\hline 13.6 & 202.88 & 10000 \\
\hline 16.8 & 250.61 & 000 \\
\hline
\end{tabular}


Comparison of results obtained using the regional and Myer methods showed that the estimated values of the maximum flood discharge in the long return periods were close to each other [11-12]. Finally, possible discharges were analyzed using Hyfa and Rank Plot numerical codes, and the discharge of the Ab-Terki River for a 95\% probability was determined, and results are shown in Table 11.

Table11. Possible discharges of the Ab-Terki River

\begin{tabular}{|c|c|c|c|c|c|c|c|c|c|c|c|c|}
\hline Aug & July & June & May & Apr & Mar & Feb & Jan & Dec & Nov & Oct & Sep & $\begin{array}{c}\text { Probability } \\
1 \%\end{array}$ \\
\hline 3.573 & 4.935 & 6.868 & 9.875 & 15.618 & 12.681 & 9.875 & 7.726 & 5.86 & 9.76 & 5.35 & 3.24 & 5 \\
\hline 3.184 & 4.334 & 5.922 & 8.566 & 13.606 & 11.61 & 8.566 & 6.357 & 4.62 & 7.61 & 4.09 & 2.78 & 10 \\
\hline 2.953 & 3.974 & 5.355 & 7.763 & 12.33 & 10.896 & 7.763 & 5.553 & 4.0 & 6.38 & 3.49 & 2.55 & 15 \\
\hline 2.784 & 3.709 & 4.937 & 7.16 & 11.354 & 10.328 & 7.16 & 4.972 & 3.59 & 5.506 & 3.11 & 2.4 & 20 \\
\hline 2.652 & 3.501 & 4.61 & 6.681 & 10.562 & 9.85 & 6.681 & 4.524 & 3.29 & 4.843 & 2.84 & 2.29 & 25 \\
\hline 2.543 & 3.328 & 4.337 & 6.274 & 9.878 & 9.427 & 6.274 & 4.156 & 3.06 & 4.305 & 2.63 & 2.2 & 30 \\
\hline 2.449 & 3.178 & 4.102 & 5.918 & 9.268 & 9.037 & 5.918 & 3.842 & 2.87 & 3.853 & 2.46 & 2.14 & 35 \\
\hline 2.367 & 3.047 & 3.894 & 5.613 & 8.715 & 8.672 & 5.6 & 3.569 & 2.71 & 3.467 & 2.32 & 2.08 & 40 \\
\hline 2.293 & 2.928 & 3.707 & 5.31 & 8.2 & 8.323 & 5.31 & 3.327 & 2.57 & 3.127 & 2.2 & 2.03 & 45 \\
\hline 2.226 & 2.82 & 8.538 & 5.03 & 7.717 & 7.991 & 5.042 & 3.109 & 2.45 & 2.827 & 2.1 & 1.99 & 50 \\
\hline 2.166 & 2.722 & 3.383 & 4.794 & 7.261 & 7.657 & 4.794 & 2.914 & 2.34 & 2.561 & 2.01 & 1.95 & 55 \\
\hline 2.109 & 2.629 & 3.236 & 4.555 & 6.814 & 7.323 & 4.555 & 2.731 & 2.24 & 2.317 & 1.92 & 1.92 & 60 \\
\hline 2.056 & 2.542 & 3.099 & 4.328 & 6.381 & 6.989 & 4.328 & 2.546 & 2.14 & 2.096 & 1.84 & 1.88 & 65 \\
\hline 2.006 & 2.46 & 2.97 & 4.111 & 5.956 & 6.648 & 4.111 & 2.409 & 2.05 & 1.896 & 1.77 & 1.86 & 70 \\
\hline 1.959 & 2.381 & 2.846 & 3.896 & 5.526 & 6.288 & 3.896 & 2.262 & 1.96 & 1.709 & 1.7 & 1.83 & 75 \\
\hline 1.914 & 2.305 & 2.726 & 3.685 & 5.091 & 5.905 & 3.685 & 2.124 & 1.87 & 1.539 & 1.64 & 1.81 & 80 \\
\hline 1.87 & 2.231 & 52.61 & 3.474 & 4.64 & 5.482 & 3.474 & 1.994 & 1.79 & 1.382 & 1.58 & 1.79 & 85 \\
\hline 1.828 & 2.158 & 2.495 & 3.256 & 4.152 & 4.987 & 3.256 & 1.869 & 1.69 & 1.237 & 1.51 & 1.77 & 90 \\
\hline
\end{tabular}

\section{CONCLUSION}

Evaluation of the duration curve showed that the Ab-Terki River has an acceptable potential for the construction of a hydroelectric power. Considering the rugged topography of the area, transferring the water to the plants from other areas is impossible. In addition, construction of hydrometric stations with suitable spatial distribution in the study area is therefore necessary.

\section{ACKNOWLEDGMENTS}

Cooperation of Farida Farid is greatly appreciated.

\section{REFERENCES}

[1] Lehner et al. (2011) High-resolution mapping of the world's reservoirs and dams for sustainable river-flow management. Frontiers in Ecology and the Environment; 9(9): 494-502.

[2] Hannah et al. (2010) Large-scale river flow archives: importance, current status and future needs. Hydrological Processes. 25(7):1191-1200.

[3] Lima IBT. (2005) Biogeochemical distinction of methane releases from two Amazon. Hydro reservoirs. Chemosphere; 59: 1697-702.

[4] Eslamian, S. S., Shahmansouri, M. R., Farid, F. (2008), Cognition Phase Studies of the Ab-terkiBazoft Rivers hydroelectric power plant, 9th National Seminar on Irrigation and Evapotranspiration, Volume III, pp. 117 (In persian).

[5] Jaramillo OA, Borja MA, Huacuz JM. (2004) Using hydropower to complement wind energy: a hybrid system to provide firm power. Renew Energy; 29 (11): 1887-909.

[6] Kalddellis JK,Katsirou V, Kondili E, Korbakis G. (2006) Optimal sizing of small hydro power plants for maximum energy production. English National Conference on the Soft Energy Resources, March 2006, Thessaloniki, Greece.

[7] Kaldellis J, Kavadias K. (2006) Computational applications of soft energy resources: wind energy hydro power.Athens: Stamoulis Editions; ISBN:960-351-631-7.

[8] Regulatory Authority of Energy (RAE). (2006) Available at /http://www.rae.grs. Athens, Greece: RAE (assessed March 2006). 
[9] Public Power Corporation (PPC), (2005) Available at /http://www.dei.grs, Athens, Greece.

[10] Simafar, Sh., (1995), Calculation and Dam Construction Principles, Naba Publications, 628 pages (In persian).

[11] Koedyk et al. (2016) Potential evapotranspiration method influence on climate change impacts on river flow: a mid-latitude case study. Hydrology Research; 47(5):951-963.

[12] Reager et al. (2014) River basin flood potential inferred using GRACE gravity observations at several months lead time. Nature Geoscience. 7(8): 588-592.

[13] Ostad-Ali-Askari, K., Shayannejad, M. 2015, Study of sensitivity of Autumnal wheat to under irrigation in Shahrekord, Shahrekord City, Iran. International Journal of Agriculture and Crop Sciences, 8 (4), 602-605.

[14] Shayannejad, M., Akbari, N., Ostad-Ali-Askari, K. 2015, Study of modifications of the river physical specifications on muskingum coefficients, through employment of genetic algorithm. International Journal of Development Research, 5(3), 3782-3785.

[15] Ostad-Ali-Askari, K., Shayannejad, M. 2015, The Reviews of Einstein's Equation of Logarithmic Distribution Platform and the Process of Changes in the Speed Range of the Karkheh River, Khuzestan province, Iran. International Journal of Development Research, 5(3), 3786-3790.

[16] Ostad-Ali-Askari, K., Shayannejad, M., Ghorbanizadee-Kharazi, H. 2015, Assessment of artificial neural network performance and exponential regression in prediction of effective rainfall, International Journal of Development Research, 5(3),3791-3794.

[17] Shayannejad, M. Akbari, N. and Ostad-Ali-Askari, K. 2015, Determination of the nonlinear Muskingum model coefficients using genetic algorithm and numerical solution of the continuity. Int. J. of Science: Basic and Applied Research, 21(1),1-14.

[18] Ostad-Ali-Askari, K., Shayannejad, M. 2015, The Study of Mixture Design for Foam Bitumen and the Polymeric and Oil Materials Function in Loose Soils Consolidation. Journal of Civil Engineering Research, 5(2), 39-44. DOI: 10.5923/j.jce.20150502.04

[19] Sayedipour, M., Ostad-Ali-Askari, K., Shayannejad, M. 2015, Recovery of Run off of the Sewage Refinery, a Factor for Balancing the Isfahan-Borkhar Plain Water Table in Drought Crisis Situation in Isfahan Province-Iran. American Journal of Environmental Engineering, 5(2): 43-46. DOI: $10.5923 / \mathrm{j}$.ajee.20150502.02

[20] Ostad-Ali-Askari, K., Shayannejad, M. 2015, Developing an Optimal Design Model of Furrow Irrigation Based on the Minimum Cost and Maximum Irrigation Efficiency. International Bulletin of Water Resources \& Development, 3(2), 18-23.

[21] Ostad-Ali-Askari, K., Shayannejad, M. 2015, Presenting a Mathematical Model for Estimating the Deep Percolation Due to Irrigation. International Journal of Hydraulic Engineering, 4(1), 17 21. DOI: 10.5923/j.ijhe.20150401.03.

[22] Ostad-Ali-Askari, K., Shayannejad, M. 2015, Usage of rockfill dams in the HEC-RAS software for the purpose of controlling floods. American Journal of Fluid Dynamics, 5(1), 23-29. DOI: 10.5923/j.ajfd.20150501.03.

[23] Soltani Todeshki, A. R., Ostad-Ali- Askari, K., Shayannejad, M. 2015, The effect of heterogeneity due to inappropriate tillage on water advance and recession in furrow irrigation. Journal of Agricultural Science, 7(6), 127-136.

[24] Soltani-Todeshki, A. R., Shayannejad, M., Ostad-Ali-Askari, K. 2015, Effects of magnetized municipal effluent on some chemical properties of soil in furrow irrigation. International Journal of Agriculture and Crop Sciences, 8(3), 482-489.

[25] Ostad-Ali-Askari, K., Shayannejad, M. 2015, Optimal design of pressurized irrigation laterals installed on sloping land. International Journal of Agriculture and Crop Sciences, ISSN 2227670X. 8(5), 792-797.

[26] Ostad-Ali-Askari K, Shayannejad M, Eslamian S, Navab-Pour B. 2016, Comparison of solution of Saint-Venant equations by characteristics and finite difference methods for unsteady flow analyzing in open channel. International Journal of Hydrology Science and Technology, 6(3), 918. 
[27] Ostad-Ali-Askari K, Shayannejad M, Eslamian S, et al. 2017, Deficit Irrigation: Optimization Models. Management of Drought and Water Scarcity. Handbook of Drought and Water Scarcity, Taylor \& Francis Publisher, USA. Vol. 3. $1^{\text {th }}$ Edition, pp: 373-389.

[28] Eskandari S, Hoodaji M, Tahmourespour A, Abdollahi A, Mohammadian-Baghi T, Eslamian S, Ostad-Ali-Askari K. 2017, Bioremediation of Polycyclic Aromatic Hydrocarbons by Bacillus Licheniformis ATHE9 and Bacillus Mojavensis ATHE13 as Newly Strains Isolated from OilContaminated Soil. Journal of Geography, Environment and Earth Science International, 11(2): $1-11$.

[29] Shayannejad M, Soltani Tudeshki A.R, Ostad-Ali-Askari K, Eslamian S, et al. 2017, Development of a new method for determination of infiltration coefficients in furrow irrigation with natural non-uniformity of slope. Sustain. Water Resour. Manag., 3(2): 163-169.

[30] Shojaei N, Shafaei-Bejestan M, Eslamian S, Marani-Barzani M, P. Singh V, Kazemi M, OstadAli-Askari K. 2017, Assessment of Drainage Slope on the Manning Coarseness Coefficient in Mountain Area. International Journal of Constructive Research in Civil Engineering (IJCRCE), 3(1): 33-40.

[31] Bahmanpour H, Awhadi S, Enjili J, Hosseini S.M, Raeisi Vanani H, Eslamian S, Ostad-AliAskari K. 2017, Optimizing Absorbent Bentonite and Evaluation of Contaminants Removal from Petrochemical Industries Wastewater. International Journal of Constructive Research in Civil Engineering (IJCRCE), 3(2): 34-42.

[32] Shayannejad M, Eslamian S, Gandomkar A, Marani-Barzani M, Amoushahi-Khouzani M, Majidifar Z, Rajaei-Rizi F, Kazemi M, P. Singh V, Dehghan SH, Shirvani-Dastgerdi H.R, Norouzi H, Ostad-Ali-Askari K. 2017, A Proper Way to Install Trapezoidal Flumes for Measurements in Furrow Irrigation Systems. International Journal of Research Studies in Agricultural Sciences (IJRSAS), 3(7): 1-5.

[33] Dehghan Sh, Kamaneh S.A.A., Eslamian S, Gandomkar A, Marani-Barzani M, AmoushahiKhouzani M, Singh V.P., Ostad-Ali-Askari K. 2017, Changes in Temperature and Precipitation with the Analysis of Geomorphic Basin Chaos in Shiraz, Iran. International Journal of Constructive Research in Civil Engineering (IJCRCE), 3(2): 50-57.

[34] Ostad-Ali-Askari K, Shayannejad M. 2016, FLOOD ROUTING IN RIVERS BY MUSKINGUM'S METHOD WITH NEW ADJUSTED COEFFICIENTS. International Water Technology Journal, IWTJ, 6(3): 189-194.

[35] Ostad-Ali-Askari K, Shayannejad M, Ghorbanizadeh-Kharazi H. 2017, Artificial Neural Network for Modeling Nitrate Pollution of Groundwater in Marginal Area of Zayandeh-rood River, Isfahan, Iran. KSCE Journal of Civil Engineering, 21(1):134-140. Korean Society of Civil Engineers. DOI 10.1007/s12205-016-0572-8.

[36] Soltani-Toudeshki A.R, Shayannejad M, Ostad-Ali-Askari K, Ramesh A, Singh V.P., Eslamian S. 2017, Wastewater and Magnetized Wastewater Effects on Soil Erosion in Furrow Irrigation. International Journal of Research Studies in Agricultural Sciences (IJRSAS), 3(8): 1-14. http://dx.doi.org/10.20431/2454-6224.0308001.

[37] Shayannejad M, Soltani-Toudeshki A.R, Arab M.A, Eslamian S, Amoushahi-Khouzani M, Marani-Barzani M, Ostad-Ali-Askari K. 2017, A Simple Method for Land Grading Computations and its Comparison with Genetic Algorithm (GA) Method. International Journal of Research Studies in Agricultural Sciences (IJRSAS), 3(8): 26-38.

[38] Mohieyimen P, Eslamian S, Ostad-Ali-Askari K, Soltani M. 2017,Climate Variability: Integration of Renewable Energy into Present and Future Energy Systems in Designing Residential Buildings. International journal of Rural Development, Environment and Health Research(IJREH), 1(2): 18-30.

[39] Saket, R. K. and Eslamian, S., 2015, Use of Wastewater for Hydroelectric Power Generation, Urban Water Reuse Handbook, Ch. 63, Ed. By Eslamian, S., Taylor and Francis, CRC Group, 827-838.

[40] Eslamian S., Shahmanosouri, M., A. Gohari, 2007, Study The Quality of Abterki River (Bazoft basin) for Hydroelectric Design, the 9th Seminar of Irrigation and Reduce Evaporation. University of Shahid Bahonar, Kerman, Iran.

[41] Eslamian S., Shahmanosouri, M., A. Gohari, 2007, Study The Quality of Abterki River (Bazoft 
basin) for Hydroelectric Design, the 9th Seminar of Irrigation and Reduce Evaporation. University of Shahid Bahonar, Kerman, Iran.

[42] Gholami. A., Mahdavi, M. and S. Eslamian, 2012, Probability Distribution Choices for Minimum, Mean and Maximum Discharges, by L-Moments in Mazandaran Province, IRAN, Journal of Flood Engineering, Vol. 3, No. 1, 83-92.

[43] Dhital, Y. P., Kayastha, R. B. and S. S. Eslamian, 2011, Precipitation and discharge pattern analysis: a case study of Bagmati River basin, Nepal, Journal of Flood Engineering, Vol. 2, No. 1, 49-60.

[44] Eslamian, S. S. and M. J. Khordadi, 2009, Comparing Rainfall and Discharge Trends in Karkhe Basin, Iran, International Journal of Ecological Economics \& Statistics (IJEES), Vol. 15, No. F09, 114-122.

[45] Hosseini, S. Z., Heidarpour, M., Eslamian, S. S., 2012, Effect of Conductor of Baldes Submerged Weir discharge coefficient triangle with vertex angle of 45 degrees, Ninth International Conference on River Engineering, Ahvaz.

[46] Bahmani, R., Eslamian, S. S., Naderi-Bani, M., Fahhian F., 2012, Investigating Maximum Rainfall Intensity on Peak Discharge using IDF curves and HEC-HMS model, Ninth International Conference on River Engineering, Ahvaz.

[47] Shabanlou, S., Rajabi, A., Eslamian, S. and Mousavi, S. F., 2012, Evaluation of empirical relationships for estimation of instantaneous peak flow Discharge in western catchments of IRAN, Iranian Water Research Journal, Vol. 6, No. 10, 215-219.

[48] Izadbakhsh, M. A., Eslamian, S. S. and S. F. Mousavi, 2001, Maximum-daily mean-discharge predicting models using physiographic characteristics of catchments in some western Iran watersheds, Journal of Science and Technology of Agriculture and Natural Resources, Vol. 5, No. 2, 1-13.

[49] Eslamian, S. S., A. Abrishamchi and K. Farzamnia, 2001, Application of discriminant analysis to estimate instantaneous maximum discharge for catchments in west of Iran, ESTEGHLAL, Journal of Engineering, Vol. 19, No. 2, 179-190.

[50] Eslamian, S. S., Salimi V. and S. Chavoshi-Boroujeni, 2000, Developing an empirical model for the estimation of peak discharge in some catchments in western Iran, Journal of Science and Technology of Agriculture and Natural Resources, Vol. 4, No. 2, 1-12.

[51] Shayannejad M, Ostad-Ali-Askari K, Eslamian S, et al. 2017, Flow Hydraulic Investigation of the Wastewater on the Soil and Magnetic Field Effects in This Field. International Journal of Constructive Research in Civil Engineering (IJCRCE), 3(3): 1-15.

[52] Shayannejad M, Eslamian S, Singh V.P., Ostad-Ali-Askari K, et al. 2017, Evaluation of Groundwater Quality for Industrial Using GIS in Mountainous Region of Isfahan Province, KohPayeh, Isfahan, Iran. International Journal of Constructive Research in Civil Engineering (IJCRCE), 3(3): 24-37.

[53] Yihdego Y, Ostad-Ali-Askari K, Namadi A, Rajaei-Rizi F, et al. 2017, Survey of Tolerable Hydrogeology Submission Approximation and Its Obscurity, Sydney, New South Wales, Australia. International journal of Rural Development, Environment and Health Research (IJREH), 1(3): 58-75.

[54] Eslamian S, P. Singh V, Ostad-Ali-Askari K, R. Dalezios N, Yihdego Y, et al. 2017, Assessment of Aridity Using Geographical Information System in Zayandeh-Roud Basin, Isfahan, Iran. International Journal of Mining Science (IJMS), 3(2): 49-61.

\section{AUTHORS' BIOGRAPHY}

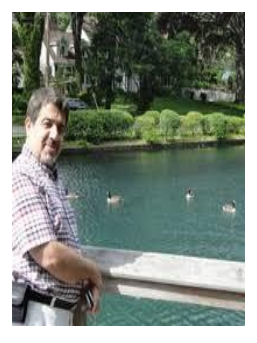

Professor Saeid Eslamian, is a full professor of water system engineering in the Department of Water Engineering at Isfahan University of Technology, Iran, where he has been since 1995. He received his PhD from Civil and Environmental Engineering School, University of New South Wales, Sydney, Australia, under the supervision of Professor David Pilgrim. His research focuses mainly on water resources planning, management, and sustainability and statistical and environmental hydrology in a changing climate. Formerly, he was a visiting professor at Princeton University, New Jersey, and University of ETH Zurich, 
Switzerland. On the research side, he started a research partnership in 2014 with McGill University, Montreal, Quebec, Canada. He has contributed to more than 650 publications in journals, books, or as technical reports. He is the founder and chief editor of both the International Journal of Hydrology Science and Technology (Scopus, Inderscience) and the Journal of Flood Engineering. Professor Eslamian is also associate editor of the Journal of Hydrology (Elsevier) and Ecohydrology and Hydrobiology (Elsevier). He has authored more than 150 book chapters and books. Recently, Professor Eslamian published eight handbooks with Taylor \& Francis Group (CRC Press) as chief editor: a three-volume Handbook of Engineering Hydrology (2014), Urban Water Reuse Handbook (2015), a three-volume Handbook of Drought and Water Scarcity (2017), and Underground Aqueducts Handbook (2016).

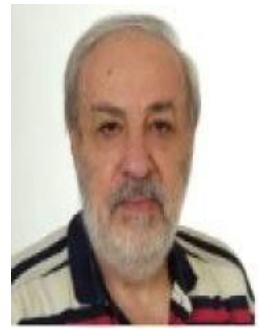

Professor NicolasR. Dalezios, is a professor of agro-meteorology and remote sensing, University of Thessaly, Volos Hellas; president of the Council of the Agricultural University of Athens, Hellas; and professor and founding director of the Laboratory of Agro-meteorology, University of Thessaly, Volos Hellas (19912011). He has done his postgraduate studies in meteorology (Athens, 1972) and hydrological engineering (University of Delft, 1974) and his $\mathrm{PhD}$ in civil engineering (University of Waterloo, Canada, 1982). He has a longstanding research record in agro-meteorology, agro-hydrology, remote sensing, modeling, environmental hazards, risk assessment, climate variability/change. He is the author or co-author in over 280 refereed publications and technical and scientific publications, member of editorial boards and reviewer in international scientific journals, editor or co-editor in over 20 edited publications, and co-author in about 35 book chapters.

Mahboubeh Amoushahi-Khouzani, Water Engineering Department, Science and Research Branch, Islamic Azad University, Tehran, Iran

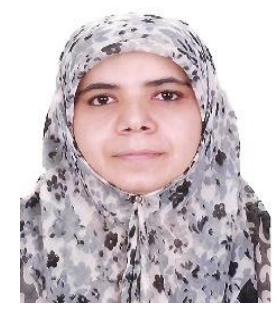

Maryam Marani-Barzani, Department of Geography, University of Malaya (UM),50603 Kuala Lumpur, Malaysia.Member of Suggestion Committee in Ministerial of Education in Iran(2002-2007). Member of Research on Heat Sink Capability of Inland Water Resources for Thermal Power Plants in Peninsular Malaysiaproject (TNBR)(2014-2015). Member of Board Trustees at Consultant Engineering Company (SharsazanZendeh Rood) in Iran.(2015-peresent).

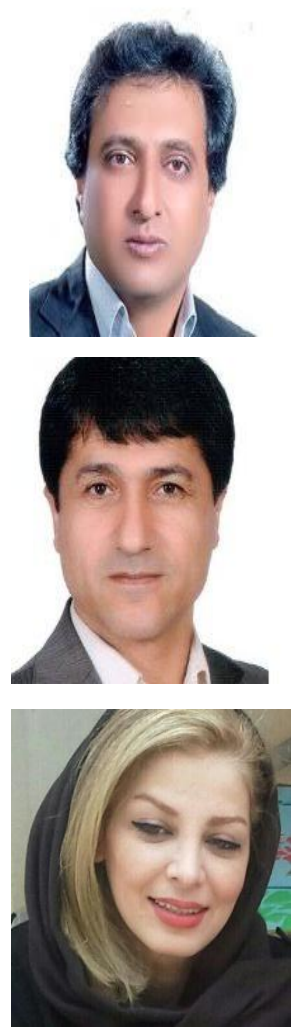

Dr. Amir Gandomkar, Department of Geography, Najafabad Branch, Islamic Azad University, Najafabad, Iran.

Dr. Morteza Khodagholi, Isfahan Center for Research of Agricultural Science and Natural Resources, Department of Climate Change \& Drought, Isfahan, Iran.

Foroozan Rajaei-Rizi, Water Engineering Department, Shahrekord University, Shahrekord, Iran 


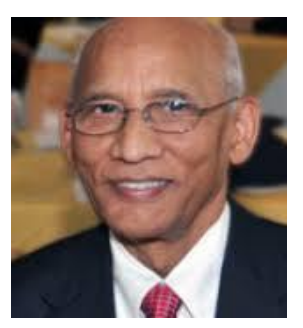

Professor VijayP. Singh, Ph.D., D.Sc., D. Eng. (Hon.), Ph.D. (Hon.), D.Sc. (Hon.), P.E., P.H., Hon. D. WRE, Academician (GFA), Distinguished Professor, Regents Professor, Caroline and William N. Lehrer Distinguished Chair in Water Engineering

President, FARA, President, G.B.S. Board, Editor-in-Chief, Water Science and Technology Library Bookseries, Editor, Global Water Resources Book Series, Editor-in-Chief, Journal of Ground Water Research, Editor-in-Chief, Open Agriculture, Editor, Journal of Agricultural Research, Department of Biological and Agricultural Engineering \&Zachry Department of Civil Engineering, Texas A and M University. is a professor of agro-meteorology and remote sensing, University of Thessaly, Volos Hellas; president of the Council of the Agricultural University of Athens, Hellas; and professor and founding director of the Laboratory of Agro-meteorology, University of Thessaly, Volos Hellas (1991-2011). He has done his postgraduate studies in meteorology (Athens, 1972) and hydrological engineering (University of Delft, 1974) and his $\mathrm{PhD}$ in civil engineering (University of Waterloo, Canada, 1982). He has a longstanding research record in agro-meteorology, agro-hydrology, remote sensing, modeling, environmental hazards, risk assessment, climate variability/change. He is the author or co-author in over 290 refereed publications and technical and scientific publications, member of editorial boards and reviewer in international scientific journals, editor or co-editor in over 20 edited publications, and co-author in about 35 book chapters.

Shahide Dehghan, Department of Geography, Najafabad Branch, Islamic Azad University, Najafabad, Iran.

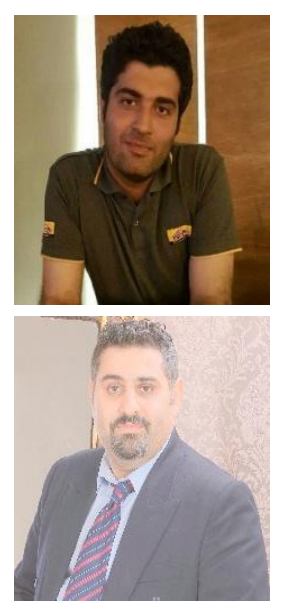

Mohsen Ghane, Department of Civil Engineering, South Tehran Branch, Islamic Azad University, Tehran, Iran. Hydrology, Irrigation and Drainage Engineering, Sustainable Development and Environmental Assessment, Climate and Integrated and Sustainable Water Resource Management, Water System Engineering, Water Resources Planning, Artificial Neural Network, and Genetic Algorithm. Currently, he is a Faculty Member of the Department of Civil Engineering, Isfahan(Khorasgan) Branch, Islamic Azad University, Iran

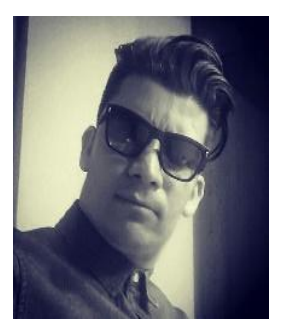

Morteza Soltani, Department of Architectural Engineering, Shahinshahr Branch, Islamic Azad University, Shahinshahr, Iran.

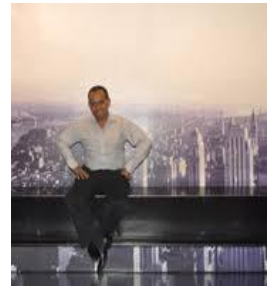

Dr. Yohannes Yihdego, Snowy Mountains Engineering Corporation (SMEC), Sydney, New South Wales 2060, Australia. GeoInformation Science and Earth Observation (ITC), University of Twente, the Netherlands. Working at Global Engineering consulting firm in Hydro-Geo-Engineering across Australia, Middle East, Asia, Africa in water, resource, mining, infrastructure, transport, energy, agriculture, landfill, contamination/pollution/remediation, environmental 
assessments, flood/urban drainage design/modelling, drought, climate change Produced hundreds' of Engineering technical -feasibility/ detail design reports \& Published several articles \& book chapters Serving as peer Reviewer \& Editor board member.

Hossein Norouzi, Department of Civil Engineering, Maybod Branch, Islamic Azad University, Maybod, Yazd, Iran.

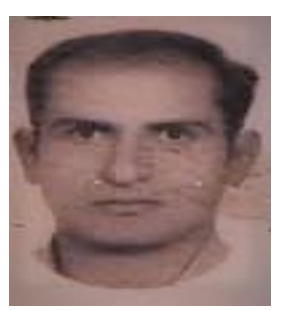

Hamid-Reza Shirvani-Dastgerdi, Department of Civil Engineering, Isfahan (Khorasgan) Branch, Islamic Azad University, Isfahan, Iran.

Citation: Dr. Kaveh Ostad-Ali-Askari et al. (2017) Hydroelectric Production using Ab-Terki River Flow Specific Energy, International Journal of Constructive Research in Civil Engineering, 3(3), pp.46-61

Copyright: () 2017 Dr. Kaveh Ostad-Ali-Askari, et al. This is an open-access article distributed under the terms of the Creative Commons Attribution License, which permits unrestricted use, distribution, and reproduction in any medium, provided the original author and source are credited. 